\title{
膽囊, 藥物學的反應二就テ
}

醫學士䇺島順吉及ビ同鶴卷龍太郎

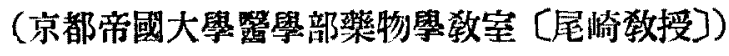

（昭和二年十月十五日受付“特〕）

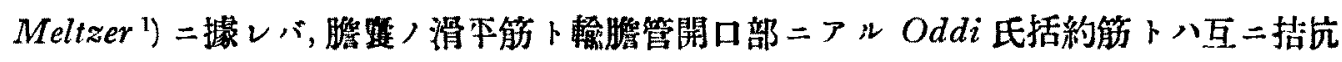

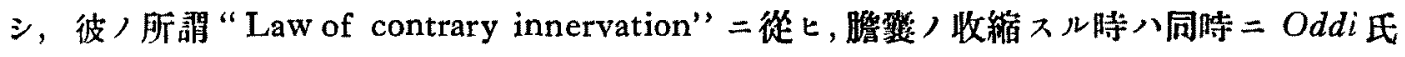

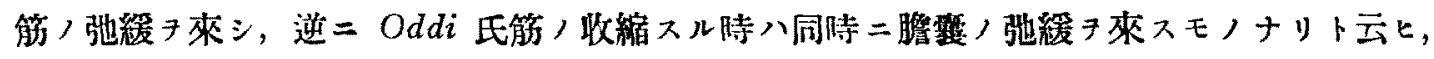

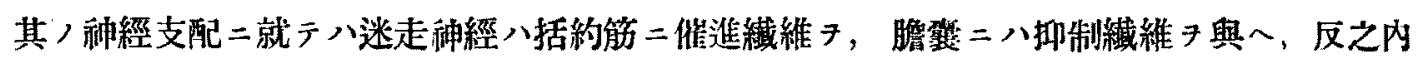

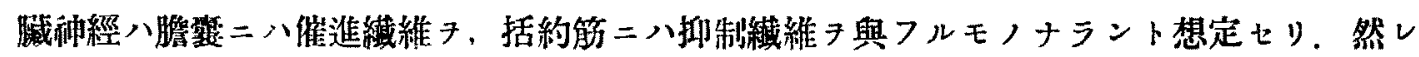
ドモ彼ノ主張八固ヨリ何等ノ賽驗的支持 タ有スルニアラズ. 彼ノ所説ニシラ果シテ正鴊 得タルモノナリト七バ，膽䇥卜 Oddi 氏筋卜八神經毒=對スル藥物學的反應二於テモ亦互 二相反七ル結果タ示スベキ理ナリトス，然レドモ彼ガ所說ノ正否，解决二資スルニ尼ルベ

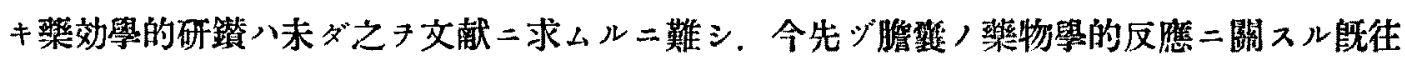

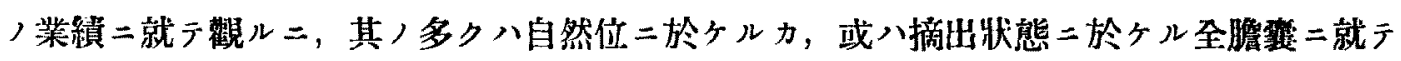
行ハレタルモノニシテ，未其ノ結果ノ一致缺キ信㕠二值スルモ/甚分少シ。

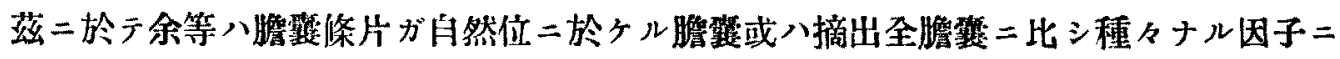

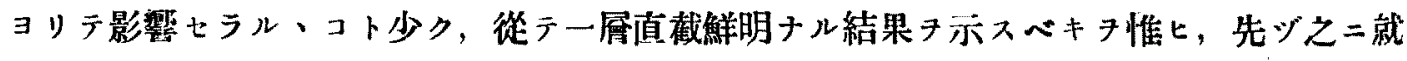
テ藥物學的反雔タ檢シ。え茲二報告セントス.

\section{貝驗材料及ビ方法}

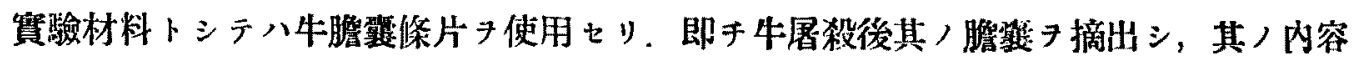

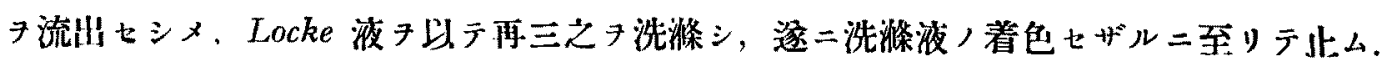
次デえキ冷藏シ，使用時二當り外被セル脂肪子完全二除去シ，長サ凡ソ $2 \mathrm{~cm}$, 幅凡》 5 


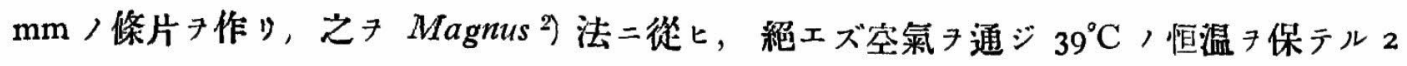
$\%$ 牛血清加 Locke 液 $50 \mathrm{ccm}$ 中二奬垂シ, 其ノ運動キ描畫セシォタリ

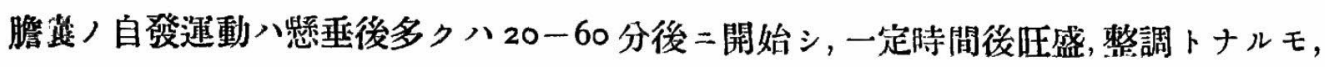
時ニハ其ノ運動甚ダ微弱二シテ且不規則ナルコトアリ 一般二横斷條片八縱断條片二比シ 其/運動活潑ナシショ以テ，圭トシテ横斷條片ニ就テ樂物學的反倠き檢セり

\section{宽 驗 成 績}

\section{1. เピロカルピンフ}

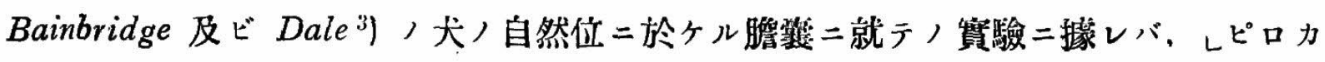

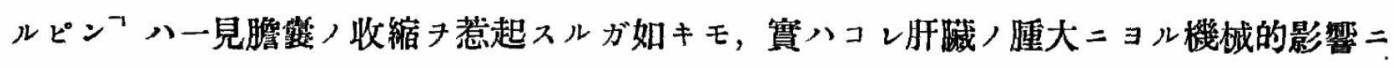

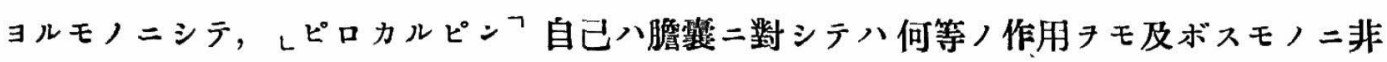

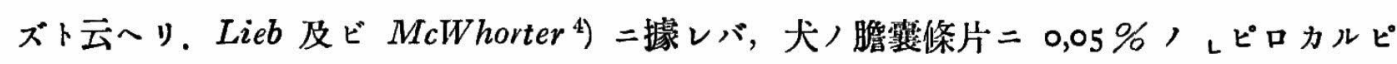

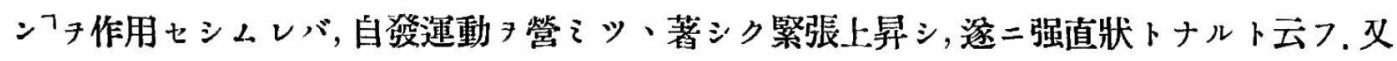

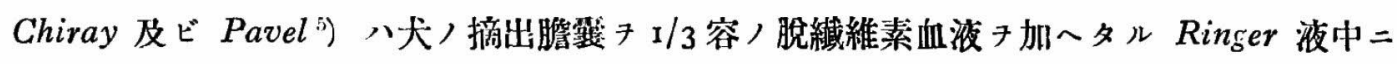

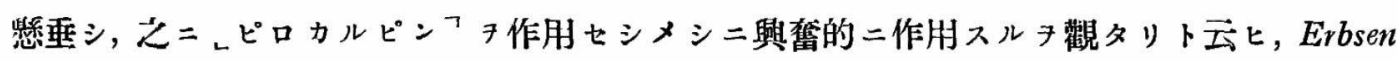
及ビ $\operatorname{Damm}^{6}$ ) モ亦摘出膽整二對シ Łピロカルピンフ ハ收縮的二作用スルタ認メタリト云 7 .

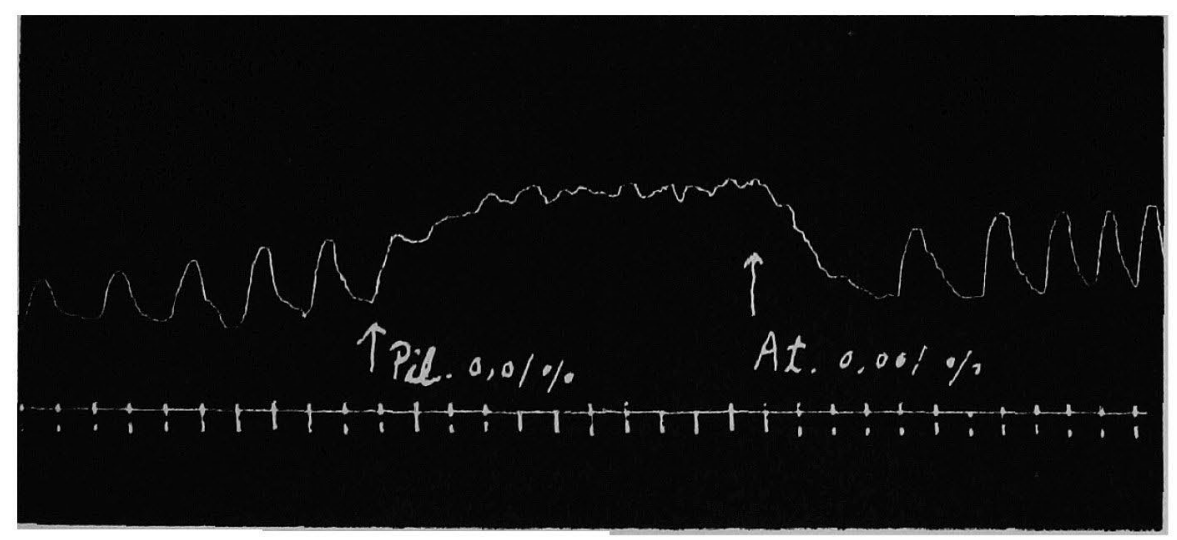

第 1 圖 $\uparrow$ Pil. : o,or \% 望酸 レビロカルビン

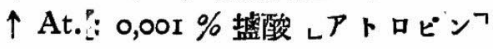

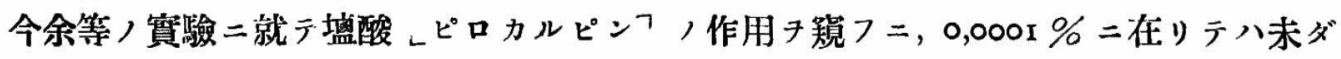
殆ド認ムべキ變化キ示サズ。 $0,001 \%$ 在リテハ時二緊張稍々上昇シ，振幅ノ縮小ォ來ス 
コトアルモ，多クハ向其ノ作用明ナラズ. $0,002 \%$ 二在リテハ多クノ場合輕度ノ緊張上昇, 振幅ノ縮小キ來スモ，時二緊張ノ上昇，振幅ノ縮小著明ニシテ且收縮ノ頻數キ來スコトア リ. $0,01 \%$ 二至レバ其ノ作用更二顯著ニシテ緊張上昇後自發運動ハ甚シク微弱トナル (第 I 圖).

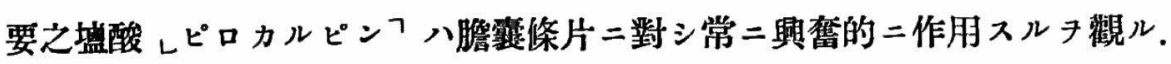

\section{2. เアセチール-ヒョリン'}

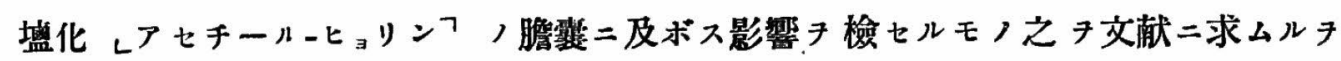
得ズ.

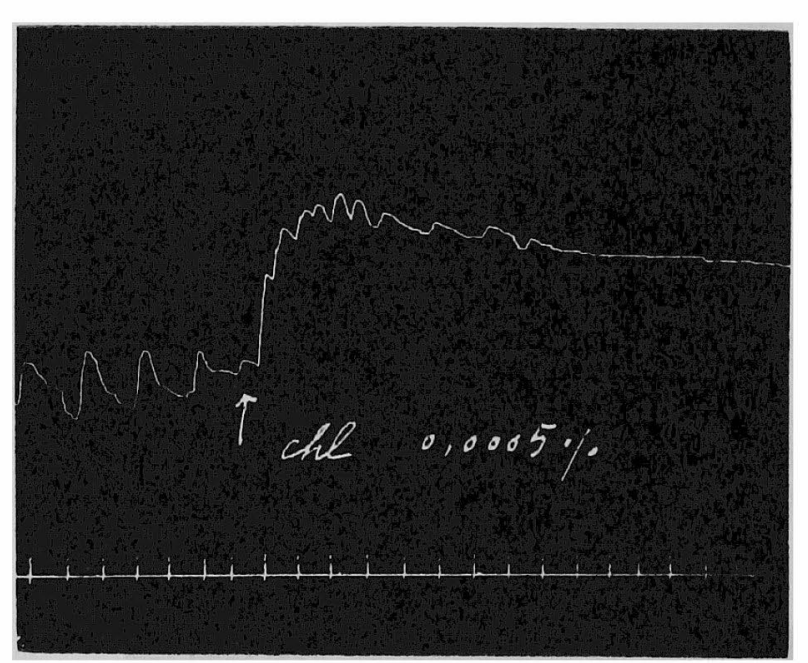

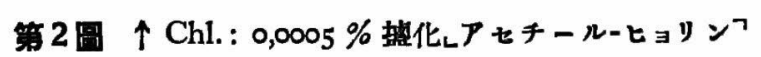

今其, 作用 7 规フ \%ニ於テハ未柋認ムべキ作用タ旺セ ズ. $0,0001-0,0005 \%$ 二在りテハ多 クノ場合緊張, 上昇, 振幅ノ縮小э 招致入(第 2 圖). $0,001-0,005 \%=$ 於テ八藥液注加後直二緊張著明二上 昇シ, 振幅/縮小キ來ス。 $0,01 \%=$ 在りテハ其ノ作用更二顯著ナルキ觀 タリ.

，要之塩化しアセチールーヒョリンフ 八膽俪條片二對シ レピロカルピンフ

ト同樣興蒢的二作用スルチ觀ル

\section{3. เピロカルピンフ 及ビ เアセチール-ヒョリンフ 興隹二對スル เアトロピンフノ關係}

レピロカルピンフ 並ニレアセキールーヒョリンフニョル腸管及ビ子宮/强度/興㤫二對

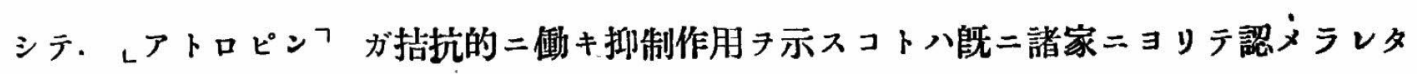
ル所ナリ今膽翼二就テ之二關スル文献キ求ムル二, Lieb 及ビ McWhorter $\left.{ }^{4}\right)$ ハ犬ノ瞻

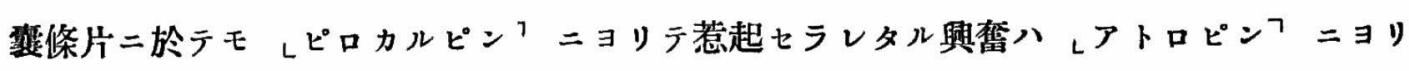

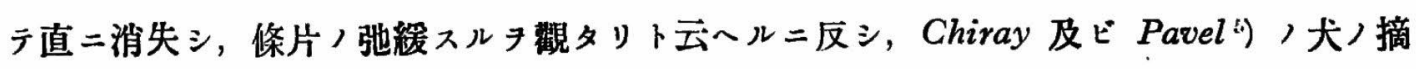




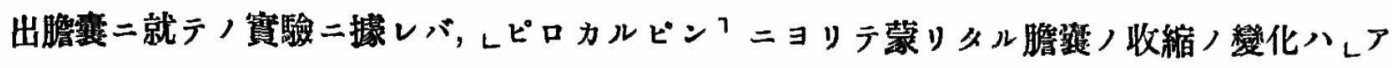
トロビンフニョリテ何等影響セラル、コトナシト云フ. 仍リテ余等ハ先ヅレピロカルピン トレアトロピンフトノ拮抗關係キ精細二追試シ, 更ニこアセチールーヒョリンフトレアトロ ピンフトノ關係タモ觀察セリ。

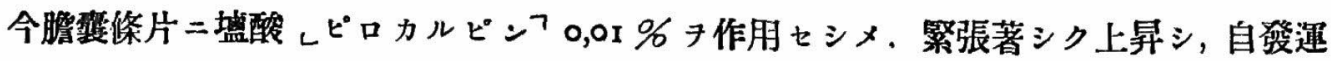
動殆ド静止スルニ近キニ及ビ，硫酸 レアトロピンフ 0,001\%キ作用セシムル二，緊張次第 ニ下降シ，4-5分ニシテ殆ド舊狀二復ジ，レピロカルピンフ作用前ト略々同栐ナル振幅

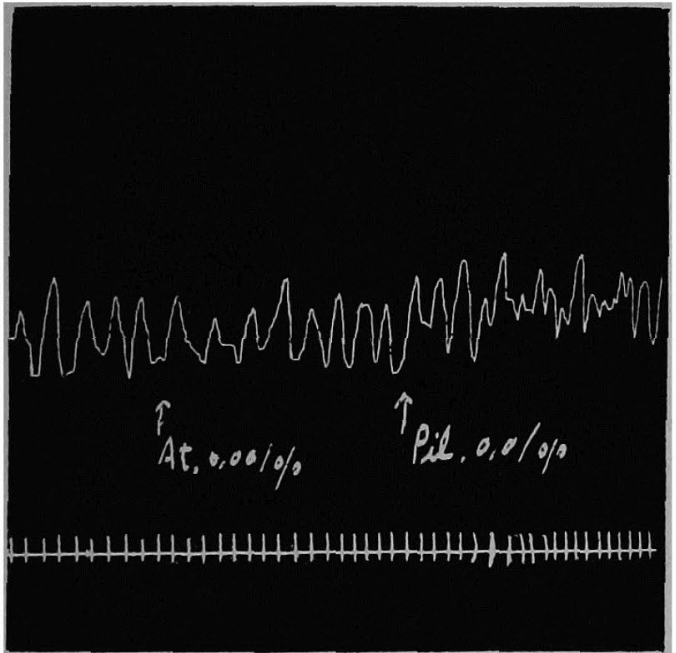

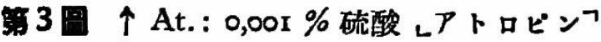
$\uparrow$ Pil.: 0,01\% \% 酸 レピロカルビン・

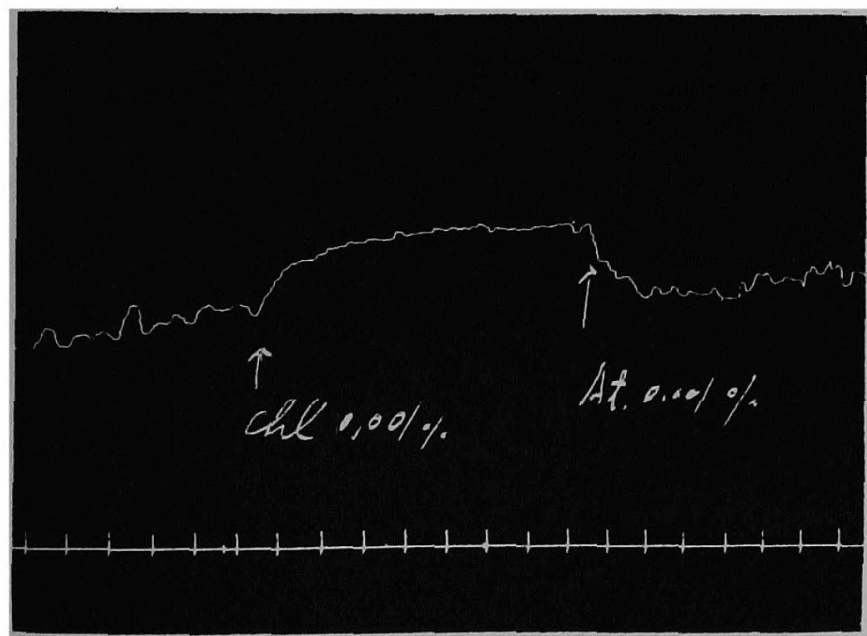

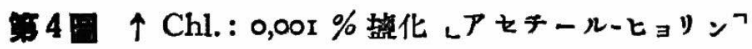
$\uparrow$ At. : 0,00I\%硫酸 レPトロピンフ
以テ自發運動ヲ營ム二至ル（第 $\mathrm{x}$ 圖）．反

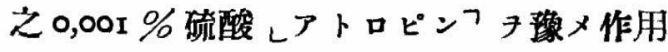
セシメタル後, 0,01\%墭酸 レピロカルピ ンフォ作用セシムルニ, 殆ド全ク作用ョ呈 セザルカ, 或八僅微ナル餐張ノ上昇, 振幅 ノ縮小ョ來スコトアルニ過ギズシテ，レピ ロカルピンファ單獨二作用セシメタル場合 二觀ルガ如キ著シキ緊張ノ上昇,. 自發運動 ノ静止 キ來スガ如キコト絕エテナシ（第 3 圖).

次二膽賴條片ニ於ヶルレアセ チールーヒョリン'興奮ニ糕スル レアトロピンフノ關係ヨ检センガ

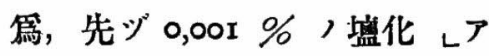
セチールーヒョリンフ キ作用セシ メ,條片ノ緊張著シク上昇シ, 自 發连動ノ殆ド靜止スルニ近キニ 及ビ, $0,001 \%$ ，硫酸しアトロピ ン’・作用セシメタルニ, 㗨張 次第二舊二復シ, 自發運動チ再 绐シ，振幅モ次第二堆大シ，殆 ド舊狀ョ呈スルニ至ルコトレピ 


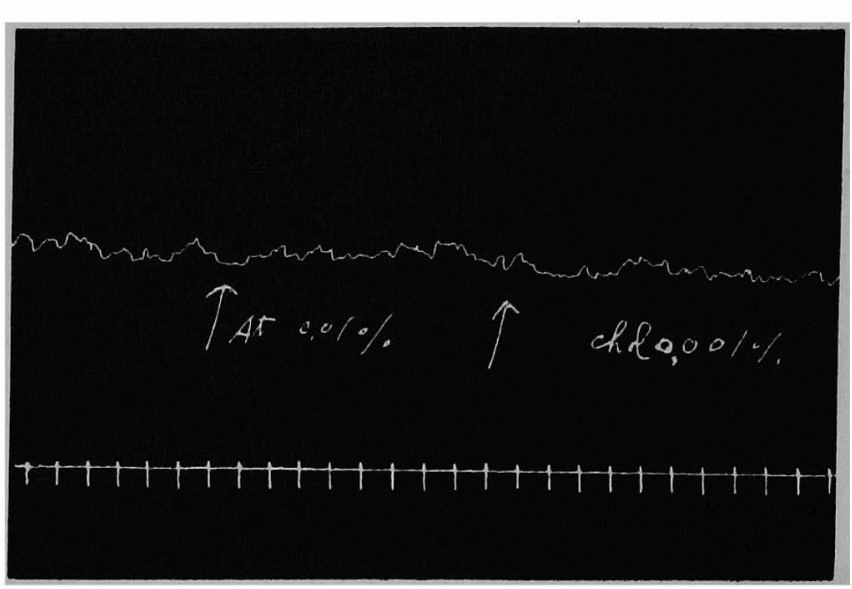

第 5 圖 $\uparrow$ At. : 0,OI \% 硫酸 レアトロピンר

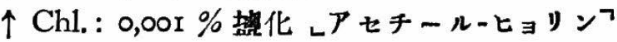

ニヨリテ拮抗セラル、モノナルコトキ知ル。
ロカルピンフノ場合二於ケルト其 ノ軦ヨー二ス(第 4 圖). 又䲞メ硫 酸レアトロピンフ 0,01％尹作用セ シメ置キタル後しアセチールーとョ リンプ,001\% \%作用セシムルモ， 該藥㸮ノ興奮作用毫モ出現スルコ トナシ(第 5 圖).

要之膽孁條片ニ於テモレピロ カルピンフ及ビレアセチールーヒ, 、 リンフニヨル興奮ハレントロピンフ

\section{4. ๖トロピンフ}

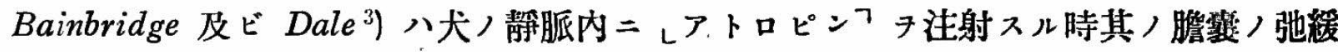
セラル、ヨ觀，又Lieb 及ビ McWhorter $\left.{ }^{4}\right)$ ノ犬ノ膽整條片二就ラ行〜ル實驗二據レバ， レアトロピンフ，作用八全ク其ノ適寿時，條片，緊張如何ニョリテ左右セラル、モ，、如 シ，即チ藥物ノ適用ニヨリ又ハ自然的二緊張ノ增加セル場合二於テハ能ク其ノ㧕制作用タ

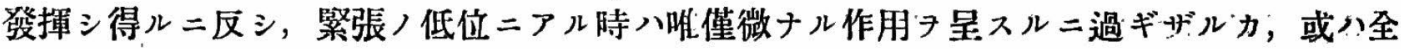
ク何等ノ作用キモ示スコトナシト 又 Chiray 及ビ Pavel ${ }^{5}$ ) 八犬ノ摘出膽霹ニょアトロ

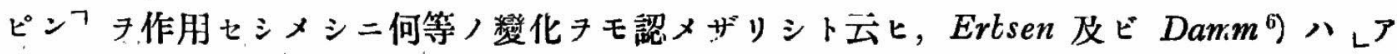

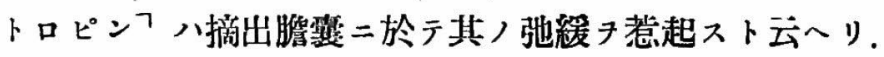

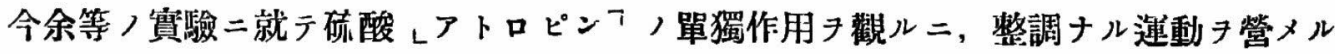

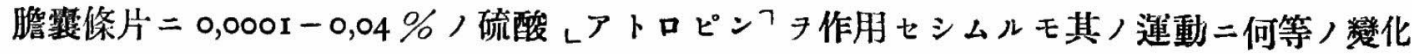

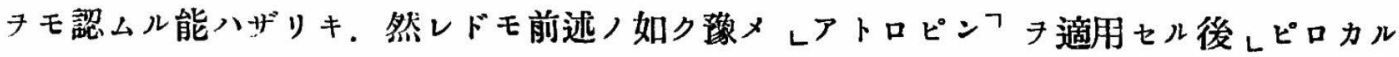
ピンフ或ハレアセチールーヒョリンフォ作用セシムルモ，明ナル興奮作用チ呈スルコトナキ

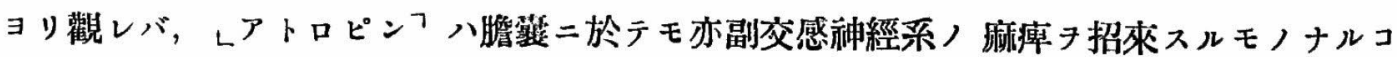
トヌ私ルキ得べシ。

\section{5. ᄂアドレナリンา}

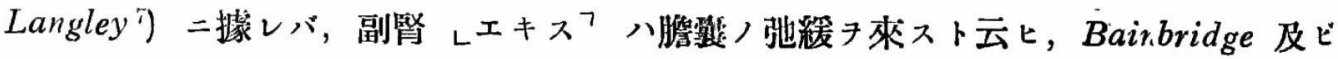




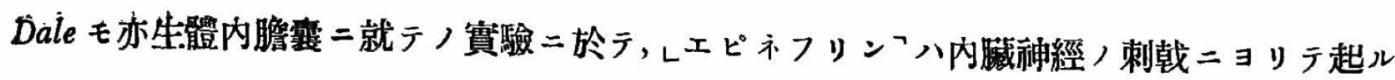

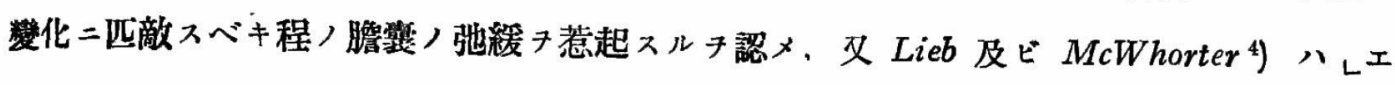

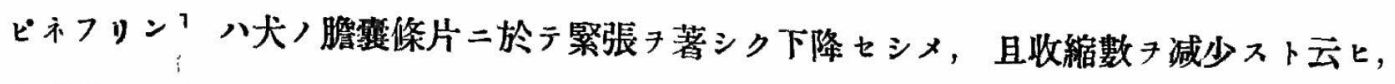

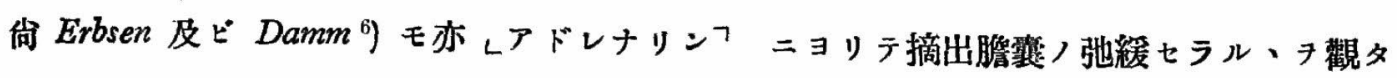

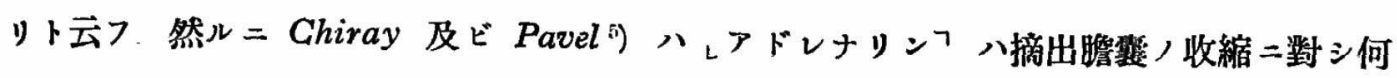
等ノ影響キモ及ボサズト云へリ。

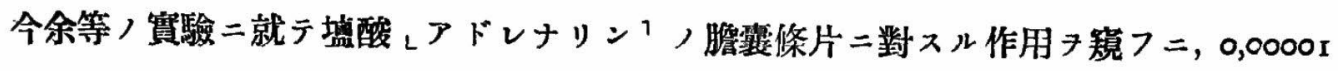
\%ニ於テハ未ダ認ムべキ作用キ星セズ $0,0001-0,0005 \%$ 二於テハ多クノ場合振幅, 縮小 キ來シ，緊張稍々下降スルモ，時二緊張却テ上舁スルコトアリ. 又稀ニ八何等ノ作用きモ 呈セザルコトアリ，0,001ー0,002\%二在リテハ緊張ハ下降スル:1トアリ(第 6 圖), 或ハ 上昇シテ長ク該狀態习持續スルコトアリテ (第7圖), 其ノ作用一定セザルモ，振幅ハ多 ク.ノ場合縮小スルキ常トス.

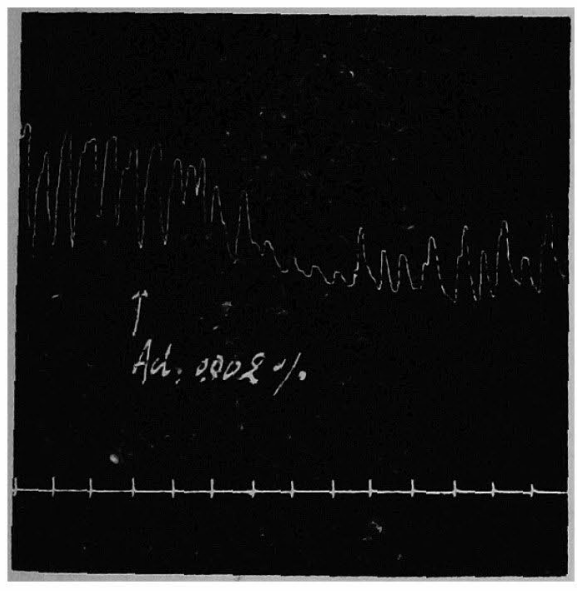

第 6 圖 $\uparrow$ Ad. : $0,002 \%$ 坡酸 レアドレナリン・

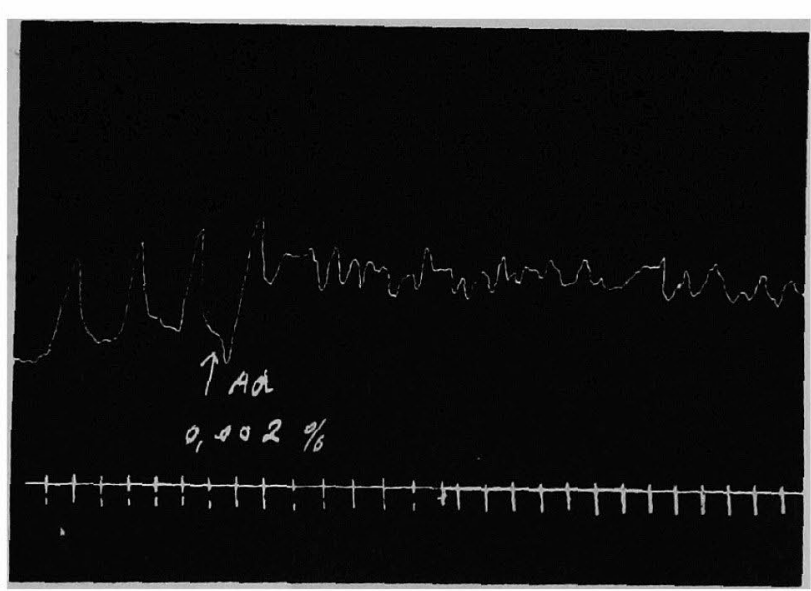

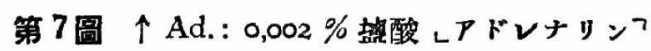

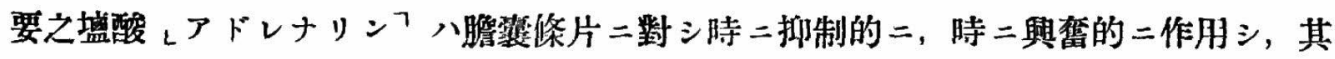
ノ作用一定セザルモノ、如シ。

\section{6.ムバリウム゙"}

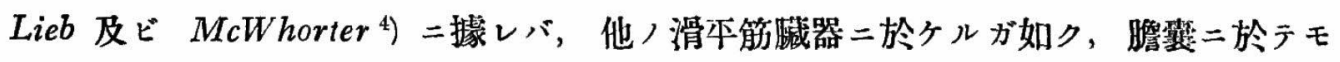

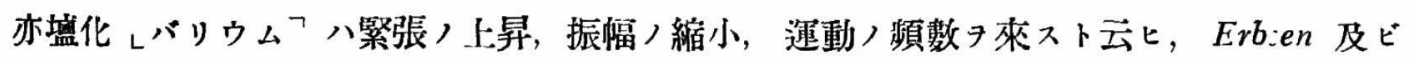

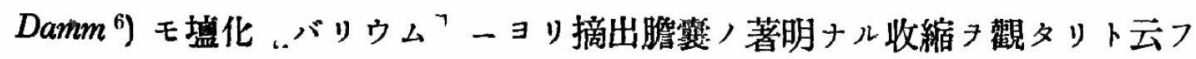




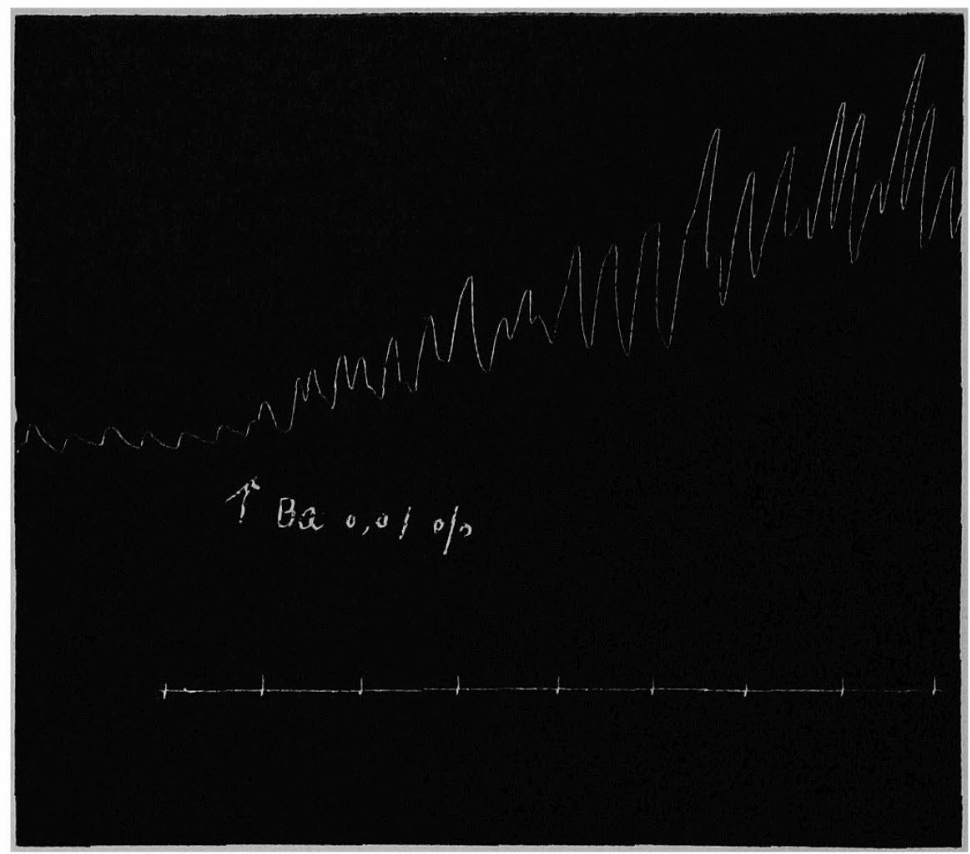

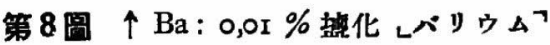

今脆靈條片二㦈化 レバリウムフ 0,002\% \%作 用セシムルニ, 時二稍々 䋜張ノ上昇キ來スガ如キ コトナキ二非ザルモ，多 クノ場合未ダ明ナル作用 ア認メ難シ. $0,005 \%=$ 於テハ多クノ場合緊張ノ 上昇, 振幅ノ絡小キ來ス。 更二濃度き增シテ 0,0I - 0,02\% \%至レバ殆ド常 二緊張著シク上昇シ，多 クハ振幅ノ縮小キ來スモ,

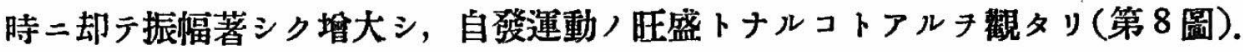

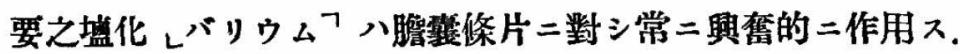

\section{7. เパパヴェリンフ}

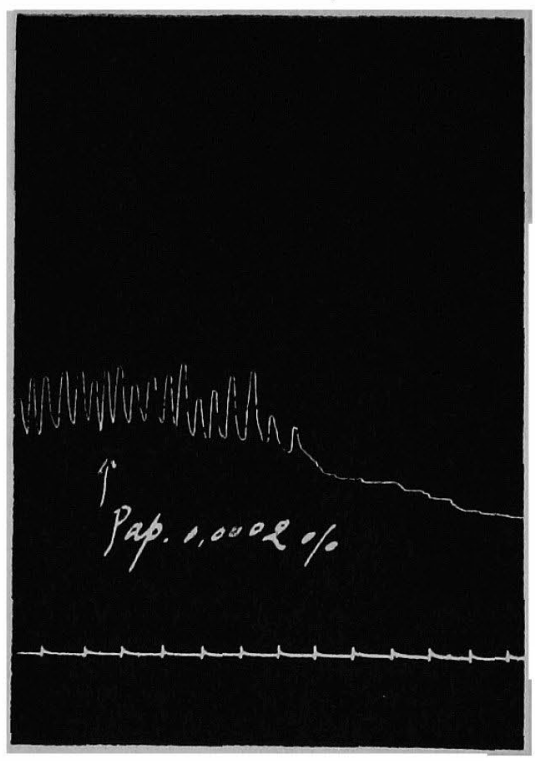

第 9 圖 $\uparrow$ Pap.：0,0002\% 墟酸 レパパヴェリンフ

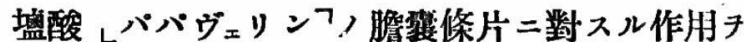
㝝う二, $0,0002 \%$ 二於テハ樂液注加後緊張次第二下 降シ,振幅モ亦减小シ，5一ro分ニシテ自發運動微弱 トナリ,遂二殆ド静止狀態二移行ス(第9圖). 0,001\% ニ在リテハ多クハ樂液注加後一二回ノ自發運動キ管 メル後直二靜止狀態二移行シ緊張亦著シク下降ス.

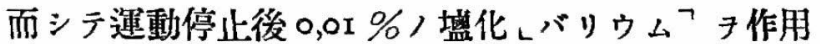
セシムルモ全ク反應キ呈スルコトナシ $\quad 0,01-0,02$ $\%$ 在りテハ藥液注加後運動八直二停止シ，緊張著 シク下降ス.

要之坥酸 レパバヴェリンフ，膽整條片二對シ麻 瘦的二作用入. 


\section{8. モ ルヒンフ}

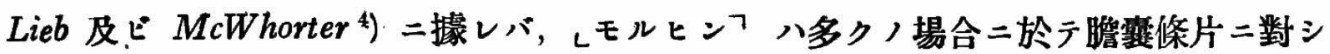
何等ノ作用チ示サザルカ, 或ハ極メラ僅微ナル緊張ノ低下ョ來スニ過ギザルモ, 稀二輕度 ノ緊張ノ上昇, 振幅ノ增大キ招致シ，收縮數ハ何等ノ垻加チモ來サザリシト云フ. 是ニョ リテ氏等ハ膽石疝痛二際シテノ レモルヒンフ，効果ハ單二中楅性ノ鎭痛作用二因ルモノニ

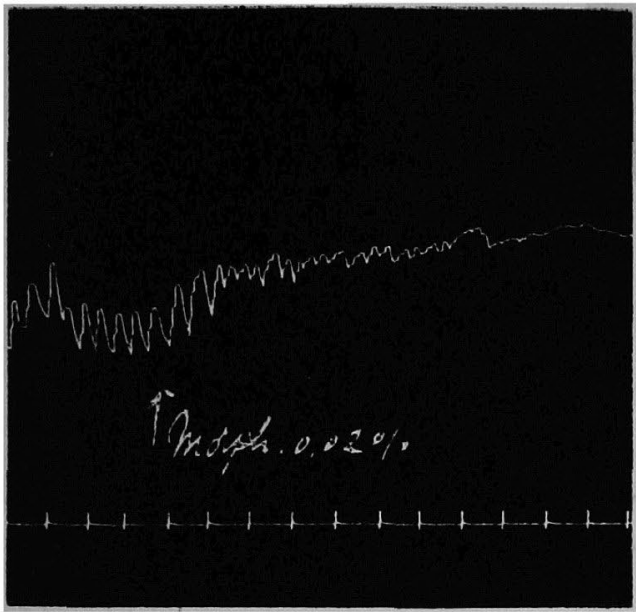

第 10 圖 $\uparrow$ Morph. : 0,02\% 越酸 レモルヒンフ シテ，膽㢣自己ニハ何等ノ直接作用ョモ及ボ スモノニ非ズト云へリ。

余等ノ實驗二就テ觀ル二, 盐酸 レモルヒ

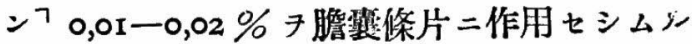
二, 多クノ場合何等作用キ呈スルコトナシ. 唯稀二緊張，上昇，振幅ノ縮小キ來シ一定時 ノ後運動殆ド静止スルコトアルタ觀タリ（第 Io 圖).

要之血酸 レモルヒンフ，膽哥條片二對シ 多クノ場合何等影䈉キ及ボスコトナキモ，時 二興奮的二作用スルコトアルキ觀ル.

\section{9. เピツイトリンフ}

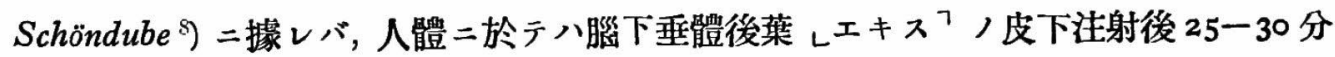
ニシテ瞻䨇内容ノ排出ガ行ハル、ト云フ 然ル $=$ Erbsen 及ビ $\operatorname{Damm}^{6}$ ) 二據レバ，摘出

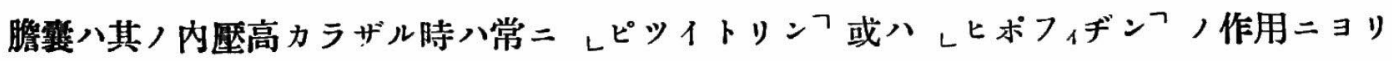
弛緩丹來ス二反シ，Tyrode 液，Locke 液或ハRinger 液キ以テ之キ充タシ,其八内厴キ高

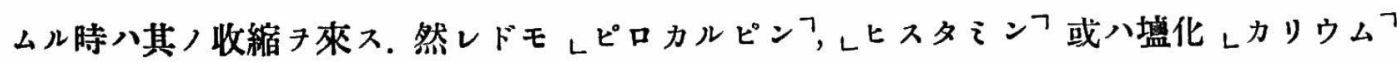

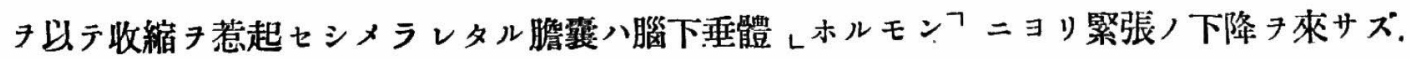

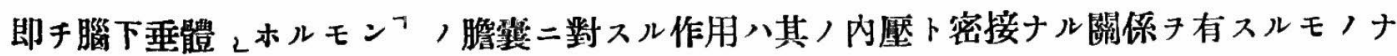
リト云ヘリ.

今膽囊條片二就テノ余等ノ實驗成績き觀ルニ, ピツイトリン ${ }^{1} 0,0005 \%$ 二在リテハ時 二緊張次第二下降シ，振幅稍々縮小スルコトアルモ，多クノ場合認ムべキ作用ナキガ如シ. 
$0,001 \%$ 二在りテハ多クノ場合㗨張,下降，振幅ノ縮小 7 來ス. $0,005 \%$ 在リテハ樂液

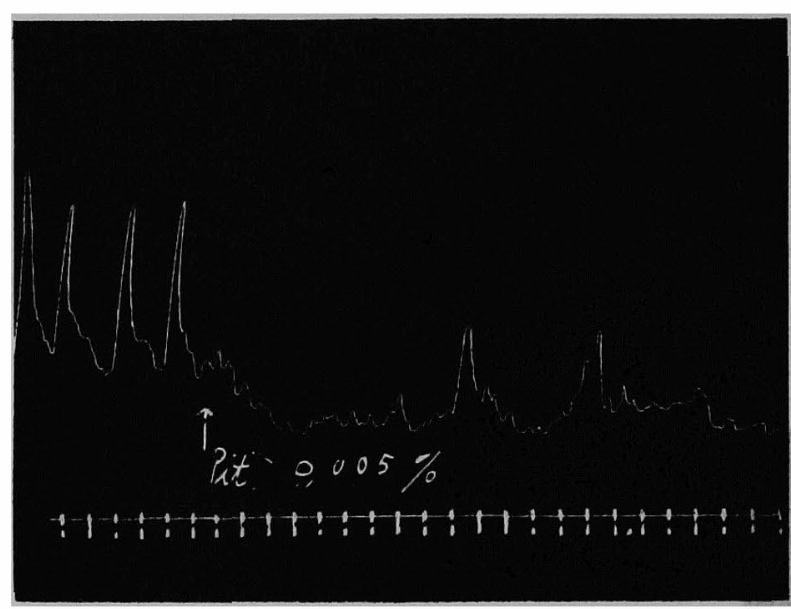

第 11 圖 个 Pit. : 0,005\% とビツイトリンフ
注加後緊張頓二著シク下降シ，自發 運動亦甚シク微弱トナル(第I圖).

要之レピツイトリンフ，膽囊條 片二對シ抑制的二作用ス.

\section{考挖}

今余等ノ得タル實驗成績ニヨリ テ膽褧ノ神經支配キ䇲ハントスルニ 當リ，先ヅ之二關スル從來ノ研究結 果ター瞥センニ, Heidenhain ${ }^{9}$ 並二

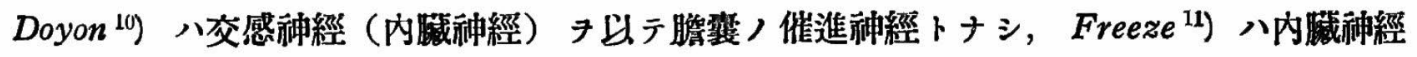

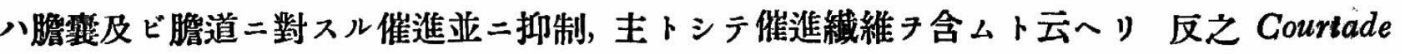

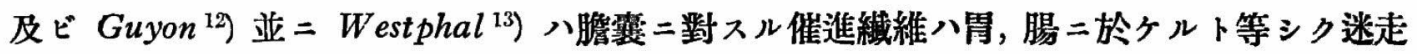
神經中二含マル、ト云ヒ, Bainbridge 及ビ Dale ${ }^{3}$ ) モ亦迷走神經 タツテ脆道二對スル催進 神經ナリト主張セルモ，占交感神經中二モ弧在的ニ八㠛進繊維モ含マル、モノナラント想 定セリ。

固ヨリ樂物學的反應ノミニョリテ神經支配ョ云々スルハ其ノ當尹得タルモノニ非ザル

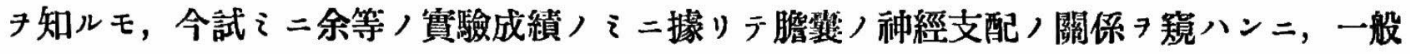
二副交感神經末梢尹興傗スト思惟セラル、こピロカルピンフ並ニレアセチールーヒョリンフ

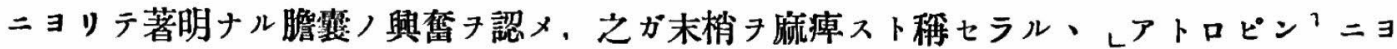
リテ該興稒ノ除去セラル、ヨリ觀レバ，Courtade 及ビ Guyon, Bainbridge 及ビ Dale-並

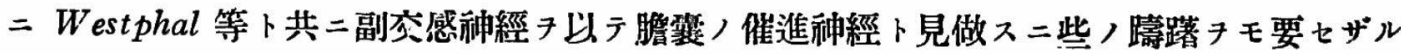
ペシ 然レドモ交感神經ガ Heidenhain 並ニDoyon，唱フルガ如ク果シテ催進瀻維ノミ タ含ムモノナリヤ. 或ハ丈 Freeze 並二 Bainbridge 及ビDa!e，主張スルガ如ク倠進,

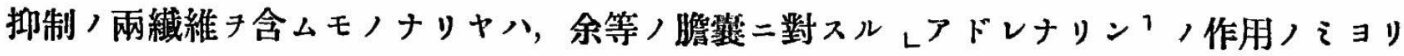
直二之キ斷定シ難キモ，レアドレナリンフ ガえ二對シ時二興奮的二, 時二抑制的二作用ス ルコトアルキ以テ觀レバ, 或ハ交感神經ハ催進, 抑制ノ兩繊維 キ含ミ, 而モ兩省ノ緊張均 等ナラズ, 時トシテハ抑制㵶維ノ緊張催進繊維ノ夫レタ淩駕シ, 時トシテハ後者ノ前者二 


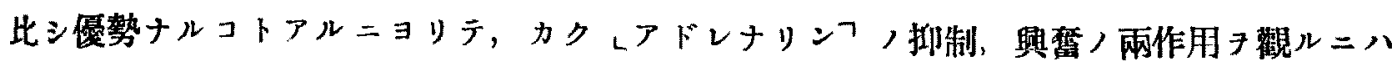
非ザルナキカ。

\begin{abstract}
總括

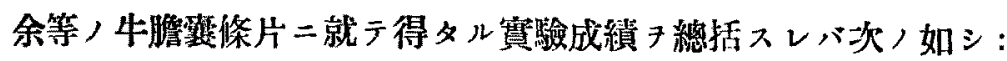

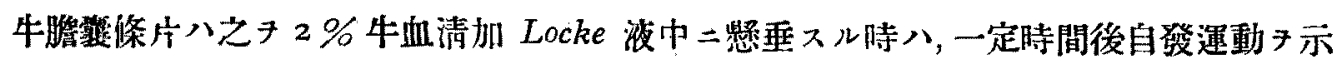

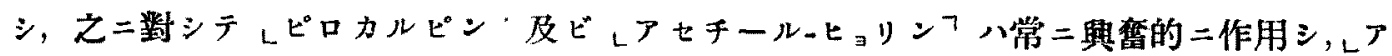
トロビンフ 八該興䅦二對シテ拈抗的二作用スルモ，單獨ニテハ其ノ作用キ示サズ、ロアド

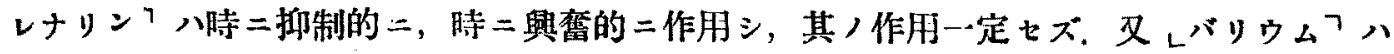

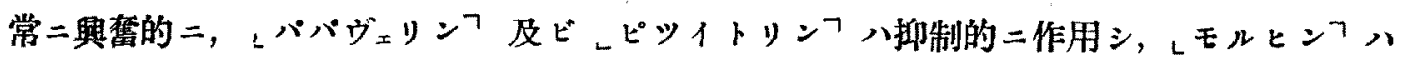
時トシテ興奮的二作用スルコトアルモ, 多クノ場合何等ノ作用ョ示サズ.
\end{abstract}

\title{
引用書目
}

I) Meltzer, Americ. Journ. of med. Sciences Vol. 153, p. 469, 1917.

2) Magnus, R., Pflügers Archiv Bd. 102, S. 123, 1904.

3) Bainbridge, F. A. and H. H. Dale, Journ. of Physiol. Vol. 33, p. 139, r905-1906.

4) Lieb, Ch. C. and F. E. McWhorter, Journ. of Pharmacol. and exp. Therapeut. Vol. 7, p. 83,1915 .

5) Chiray, M. et I. Pavel, Journ. de Physiol, et de Pathol. génér. Vol. 23, p. 318, I925.

6) Erbsen, H. u. E. Damm, Klin. Wochenschr. 6. Jg. S. 1382 , I927.

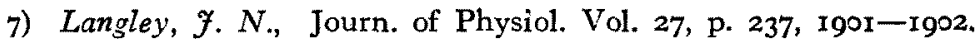

8) Schöndube, $W$., Klin. Wochenschr. 4. Jg. S. 640, 1925.

9) Heidenhain, $R$., Studien des physiol. Institutes zu Breslau Bd. 4, S. 226, I868. Zit. nach B. P. Babkin, Handb. d. normal. u. pathol. Physiol. Bd. 3, B. II, S. 798, Berlin 1927.

Io) Doyon, Arch, de Physiol. norm. et pathol. Vol. 6, p. I9, I894.

Ir) Freeze, $\mathcal{F}$. A., Bull, of the Fohns Hopkins hosp. Vol. 16, p. 235, 1905. Quoted by B. P. Babkin, 1. c.

12) Courtade, D. et F. F. Guyon, Cpt. rend. des Séances de la Soc. de Biol. T. 56, p. 313, 1904.

13) Westpha', Z., Zeitschr. f. klin. Med. Bd. 96, S. 52, r923. 